\title{
Sucrose-Enzyme Relationships in Immature Sugar- cane Treated With Variable Molybdenum, Calcium, Iron, Boron, Lead, Trichloroacetic Acid, Beta-glycerophosphate, and Starch ${ }^{1}$
}

\author{
Alex G. Alexander ${ }^{2}$
}

\section{INTRODUCTION}

Relationships have been observed in sugarcane between sucrose content and abnormal activity of the enzymes amylase $(1,2)^{3}$, invertase (2), the acid phosphatases $(1,3)$, and to a lesser extent the starch and sucrose phosphorylases $(2,6)$. The question arises as to whether or not materials applied to living cane might induce similar sucrose-enzyme relationships. Some success has been achieved toward increasing sucrose content by use of acid phosphatase inhibitors (5). This paper summarizes experiments in which $\mathrm{Mo}, \mathrm{Ca}, \mathrm{Fe}, \mathrm{B}, \mathrm{Pb}$, TCA, $\beta$-GP and starch were supplied to cane in order to evaluate their effects upon enzymes and sucrose content.

The first of three experiments employed $\mathrm{Mo}, \mathrm{Ca}$, and $\mathrm{Fe}$ in factorial combination. Molybdenum, during an earlier study, showed promise as an inhibitor of cane phosphatase (5), and at that time it was learned that the Mo effect was counteracted by high Ca. The present experiment was designed to verify the $\mathrm{Mo} \times \mathrm{Ca}$ interaction, and to test the possibility that Fe might also affect the Mo-phosphatase relationships. A second experiment likewise included variable $\mathrm{Mo}$, plus foliar applications of $\mathrm{Pb}$ and starch. As a known inhibitor of the Q-enzyme in cane (7), it was postulated that $\mathrm{Pb}$ might create more favorable reserves of glucose-1-phosphate for sucrose production. Starch was supplied in an effort to clarify the role of extremely active amylase encountered in cane (1). It was suggested (6) that amylase might serve as insurance against starch accumulation, and thus prevent the polysaccharide from becoming a competitor of sucrose for glucose-1-phosphate. If this were true, then a sudden increase in foliar starch should stimulate an immediate increase of amylase activity.

A third experiment consisted of foliar treatments with B, $\beta$-GP and TCA. Dugger and Humphreys (13) have shown B to be intimately related to

1 For convenience, the following abbreviations are used throughout this paper: Molybdenum (Mo), calcium ( $\mathrm{Ca}$ ), iron ( $\mathrm{Fe})$, boron $(\mathrm{B})$, lead $(\mathrm{Pb})$, trichloroacetic acid (TCA), beta-glycerophosphate ( $\beta$-GP), milliequivalents per liter (meq./.), parts per million (p.p.m.), indoleacetic acid (IAA), molar (M), and glucose-1-phosphate (G-1-P).

2 Associate Plant Physiologist, Agricultural Experiment Station, University of Puerto Rico, Río Piedras, P.R.

Italic numbers in parentheses refer to Literature Cited, pp. 460-61. 
enzymes of the sucrose-forming pathways, while studies at this laboratory (4) revealed that traces of $B$ stimulate a sucrose-forming mechanism of crude extracts previously inactivated by dialysis. The possibility that $\mathrm{B}$ also affects enzymes which hydrolyze starch and sucrose, and their precursors, seemed to warrant investigation. $\beta$-glycerophosphate reportedly acts as a noncompetitive inhibitor of muscle phosphorylase $(14$, p. 441$)$. It was of interest to learn whether or not this compound would inhibit starch phosphorylase of cane, and whether acid phosphatase activity would be stimulated by a sudden increase of the $\beta$-GP substrate. Trichloroacetic acid readily precipitates enzyme protein from solution and is frequently used to terminate the action of enzymes in vitro. This material was applied to immature cane to determine whether it would arrest the action of enzymes in living tissues, and, if so, whether the balance between sucroseforming and sucrose-hydrolyzing catalysts could be altered in favor of increased sucrose.

\section{MATERIALS AND METHODS}

\section{GROWTH AND SAMPLING OF PLANT MATERIALS}

All plants were of the varieties M. 336 or P. R. 980 , and were grown in the greenhouse in soil or sand culture. For experiment 1 (Mo $\times \mathrm{Ca} \times \mathrm{Fe}$ ), one-eye cuttings of the variety M. 336 were planted in No. 2 quartz sand which had been treated previously for 12 hours with $0.05 \mathrm{~N} \mathrm{HCl}$. The sand was washed with tapwater and transferred to 2-gallon polyethylene containers, fitted with glass wool over the drainage outlets. The sand of each container was thoroughly leached with distilled water prior to receiving 10 to 12 PMA-treated cuttings ${ }^{4}$. The seedlings of each container received 1 liter of distilled water daily for 4 weeks, at which time variable nutrition treatments were initiated ${ }^{5}$.

Two levels each of $\mathrm{Mo}, \mathrm{Ca}$, and $\mathrm{Fe}^{6}$ were supplied in a $2 \times 2 \times 2$ factorial combination, with 4 replicates for each of the 8 treatments. High and low levels of each variable nutrient were supplied as follows: Mo, 1 and 0 p.p.m.; $\mathrm{Ca}, 9$ and 1 meq./l.; and $\mathrm{Fe}, 6$ and 0 p.p.m. All nutrient solutions

${ }^{4}$ Cuttings were immersed in a 0.25 -percent solution of PMA (phenyl mercury acetate) and allowed to remain for $\mathbf{1 0}$ minutes. The trentment is a general antiseptic against seedborne micro-organisms.

${ }^{5}$ Nutrient concentrations, expressed as meq./l., were provided to all plants as follows: Nitrate, 10 ; phosphate, 6 ; potassium, 5 ; magnesium, 2 ; and sulfate, 2 . Constant micronutrients, expressed as p.p.m. were supplied as follows: Boron, 0.05; copper, 0.02 ; manganese, 0.50 ; and zinc, 0.05 .

6 The following compounds were used as sources for the treatment materials of these experiments: Sodium molybdate, calcium chloride, ferrous ammonium sulfate, lead acetate, boric acid, sodium $\beta$-glycerophosphate, soluble potato starch, and A.C.S. grade TCA. 
were prepared with once-distilled water and were supplied on Tuesdays, Thursdays, and Saturdays at the rate of 1 liter per container. The plants received 1 liter of distilled water per container on alternate days.

Treatments were continued until the plants were 12 weeks of age, at which time one harvest was made of leaf and meristem tissue for sugar and enzyme analyses. The basal 12 to 14 inches of leaves 0 to ${ }^{+} 4$ were frozen and prepared for extraction in accordance with procedures described previously (1). The tissue discussed herein as "meristem" consisted of an undifferentiated cylinder, about 3 inches long and somewhat less than a lead pencil in thickness, which remained after all true leaf and sheath tissue was removed from the growing point. Meristem samples were frozen and prepared for extraction in a manner identical to that described for leaves.

The plants for experiments 2 (Mo $\times \mathrm{Pb} \times$ starch) and $3(\beta$-GP $\times \mathrm{B} \times$ TCA) were grown in a Vega Alta clay loam. The soil was screened and steam-sterilized for 6 hours and then transferred to 13-inch clay containers. Twelve to fourteen one-eye cuttings of the variety P. R. 980 were planted in each container and received approximately 2 liters of tapwater at intervals of 48 hours.

Experiments 2 and 3 were initiated when the plants were 12 weeks of age. The following treatments were applied for experiment 2: Starch solutions, 1 percent and 0.1 percent; $\mathrm{Pb}, 500$ p.p.m. and 50 p.p.m.; and $\mathrm{Mo}, 80$ p.p.m. and 20 p.p.m. Experiment 3 included $\beta$-GP at rates of 1,000 and 100 p.p.m., $B$ at 500 and 50 p.p.m., and TCA at concentrations of 1 and 0.1 percent. All treatments were applied as foliar sprays with a Hudson 7.6-liter hand sprayer, operated at about 40 pounds pressure, with the nozzle adjusted for a broad, fine-mist pattern. Tween 20 was used as wetting agent at the rate of $1 \mathrm{ml}$./liter of solution. Control plants for both experiments were sprayed with distilled water-tween 20 . Treatments were applied until all above-soil areas were thoroughly wet and run-off had begun.

Experiments 2 and 3 were conducted in completely randomized designs, with three replicates for each of the seven treatments. One harvest only was taken for experiment 2, 20 days following treatment. Experiment 3 was harvested a few moments prior to treatment and again at 10 and 30 days. Leaf and meristem samples were taken and processed in like manner to those collected from experiment 1.

\section{LABORATORY ANALYSES}

Sugars and enzyme protein were extracted from the freeze-dried tissues with distilled water. Suspensions of leaf material were pretreated by ultrasonic disintegration with the aid of Branson Model S-75 sonifier, equipped with transistorized power supply and sonic converter probe. Meristem samples were extracted directly with distilled water. 
Sugar assays were conducted with clarified water extracts. Total ketose was determined colorimetrically by the resorcinol method of Roe (20), and sucrose by the modification of Cardini et al. (11), which destroys fructose by heating the samples for 10 minutes at $100^{\circ} \mathrm{C}$. in $0.25 \mathrm{~N} \mathrm{NaOH}$. Fructose was estimated by subtracting sucrose values from total ketose.

Enzyme protein was precipitated with ammonium sulfate between 30and 95-percent saturation, after the extracts had been adjusted to $\mathrm{pH} 7.0$ with $\mathrm{NaOH}$, in accordance with procedures described previously (1). Leaf enzyme preparations were dialyzed against distilled water for 2 hours. Meristem preparations, which were the sole source of invertase, were not dialyzed in order that maximum invertase action should be retained ${ }^{7}$. Protein was measured by the micromethod of Sutherland et al. (22).

Enzymes measured during the present studies included the acid phosphatases which hydrolyze $\beta$-glycerophosphate, ATP, and glucose-1-phosphate. Also included were the enzymes starch phosphorylase, amylase, invertase, peroxidase, and polyphenol oxidase. Assay procedures for phosphatases, polyphenol oxidase, and peroxidase were described in a previous report (1), as were starch phosphorylase (6), amylase (10), and invertase (9). The starch phosphorylase procedure was modified slightly by incorporating $0.001-\mu$ mole of iodide per milliliter of digest as an amylase inhibitor.

All data collected during these experiments were subjected to analysis of variance, and means were compared by the Student-Newman-Keuls $Q$ test. The results of the statistical analyses are presented in table 1.

\section{RESULTS AND DISCUSSION}

\section{EXPERIMENT 1 (MOLYBDENUM $\times$ CALCIUM $X$ IRON)}

$M o$ vs. $C a$ and $F e$, Leaves

Neither $\mathrm{Mo}, \mathrm{Ca}$, nor $\mathrm{Fe}$ appreciably affected leaf sugars as main effects, although sucrose was influenced by $\mathrm{Mo} \times \mathrm{Ca}$ and $\mathrm{Mo} \times \mathrm{Fe}$ interactions. Raising Mo from low to high caused an increase of sucrose (table 2, item 2), but this happened only when $\mathrm{Ca}$ was low. This is in agreement with previous observations (5). However, high $\mathrm{Fe}$ also prevented the Mo effect, even when Ca was low, and, in fact, the Mo effect was reversed (i.e., high Mo suppressed sucrose) when combined with low $\mathrm{Ca}$ and high $\mathrm{Fe}$. No Mo effect upon sucrose occurred when both $\mathrm{Ca}$ and $\mathrm{Fe}$ were high.

A relationship between $\mathrm{Ca}$ and $\mathrm{Fe}$ was also encountered, which, in turn, depended greatly upon Mo for its expression (table 2). Under conditions of low Mo supply, raising Fe from low to high appeared to increase sucrose when $\mathrm{Ca}$ was low. No difference was found between low and high $\mathrm{Fe}$ when

7 Sugarcane invertase is inactivated by dialysis against distilled water (9). 
TABLE 1.-Summary of significant mean differences among sugar and enzyme values in response to variable treatments 0 immature sugarcane ${ }^{1}$

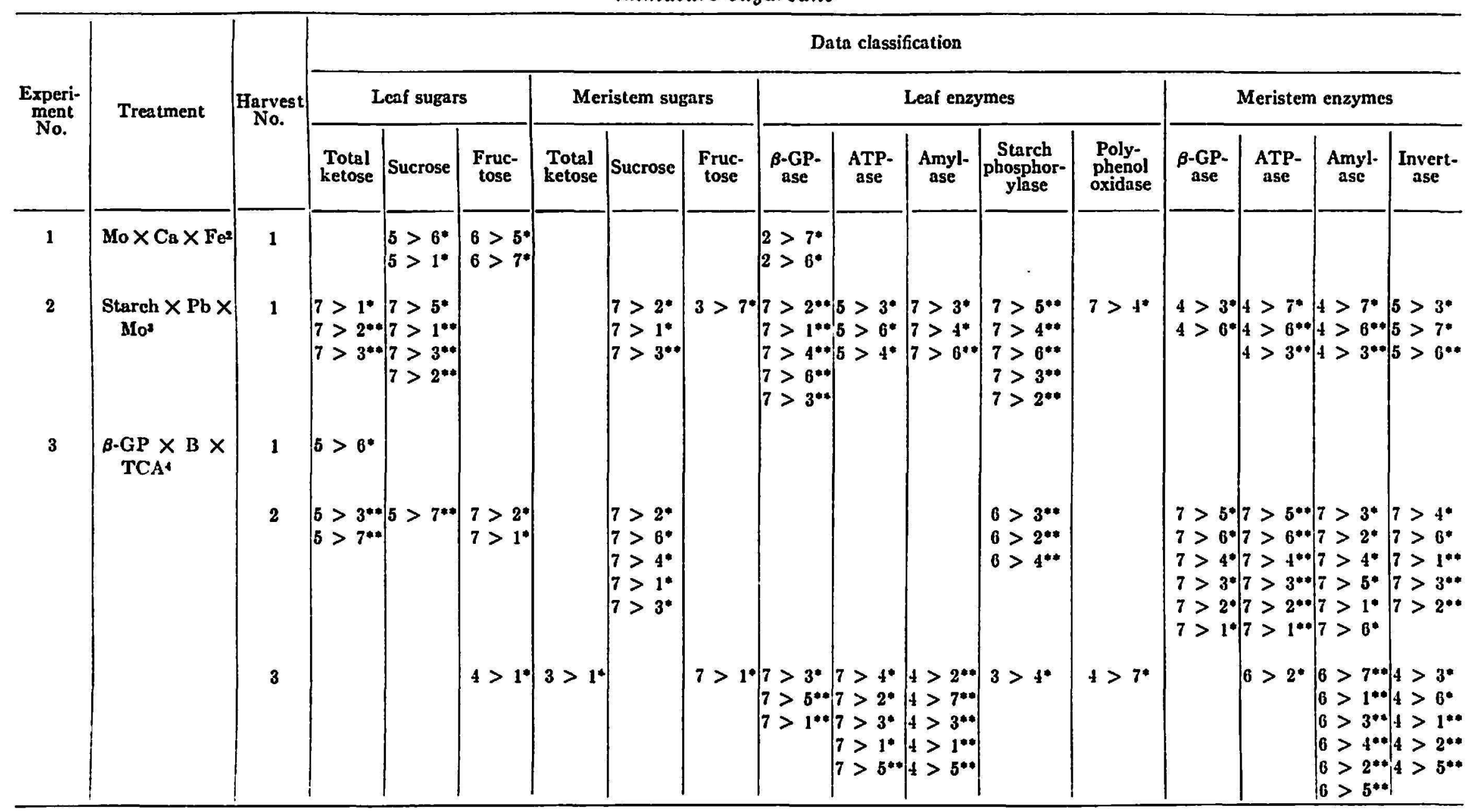

1 Figures sppenring in this table refer to treatment means from each experiment. One saterisk indicates that the difference between 2 menn values was significant at the 5-percent level, and 2 asterisks denote a significant difference at the 1-percent level. For example, the notation $5>6 *$ tells us that the mean value for treatment 5 was greater than that of treatment 6 , and that the mean difierence was significant at the 5-percent level.

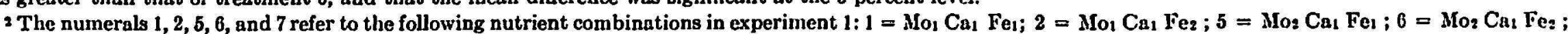
and $7=\mathrm{Mo}_{2} \mathrm{Ca} \mathrm{Fe}_{1}$.

The numerals 1 through 7 refer to the following treatments in experiment $2: 1=$ control; $2=$ low starch; $3=$ bigh starch; $4=$ low $\mathrm{Pb} ; 5=$ high $\mathrm{Pb} ; 0=$ low $\mathrm{Mlo}$; and 7 = high Mo.

The numerals 1 through 7 refer to the following treatments in experiment $3: 1=$ control; $2=\operatorname{low} \beta-G P ; 3=$ high $\beta-G P ; 4=$ low B; $5=$ high B; $6=$ low TCA; and $7=$ high TCA. 


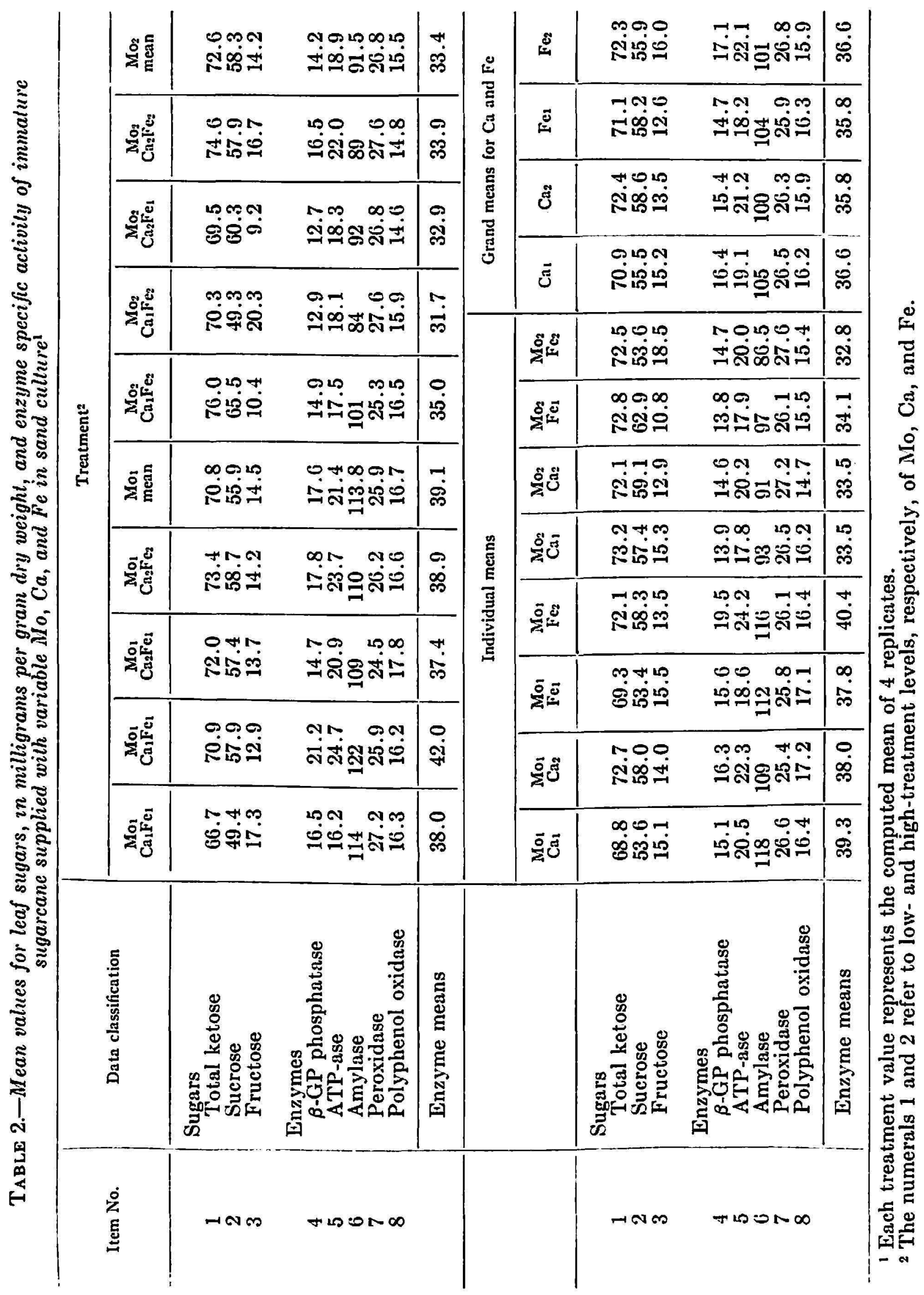


Ca was high. Under conditions of high Mo supply, however, high Fe definitely suppressed sucrose, as compared with low Fe, at the low Ca level, and again no $\mathrm{Fe}$ effect was apparent at the high $\mathrm{Ca}$ level. It thus appears that $\mathrm{Fe}$ was permitted a range of potential effects when $\mathrm{Ca}$ was low, the expression of $\mathrm{Fe}$ then being dependent upon Mo, while $\mathrm{Fe}$ had little influence upon sucrose when Ca was high, at either of the Mo concentrations.

Our original interest in Mo lay in its ability to inhibit phosphatases, and it was postulated that the element would promote sucrose formation by suppressing enzymes which hydrolyze phosphorylated precursors of sucrose. As main effects, high Mo suppressed slightly both $\beta$-glycerophosphatase and ATP-ase (table 2, items 5 and 6). Yet individual Mo effects fluctuated greatly in the presence of variable $\mathrm{Ca}$ and $\mathrm{Fe}$, and did not yield the expected sucrose responses. For example, the strongest suppression of both phosphatases occurred when Mo was raised from low to high, in conjunction with low $\mathrm{Ca}$ and high $\mathrm{Fe}$. This treatment caused a sucrose suppression rather than an increase. Again, high Fe apparently stimulated phosphatase when $\mathrm{Ca}$ and Mo were low, and this treatment caused a sucrose increase rather than decline. The only Mo-phosphatase-sucrose relationship that coincided with the proposed theory was shown by $\beta$-glycerophosphatase when Mo was raised from low to high, in conjunction with low $\mathrm{Ca}$ and low Fe.

We are fairly certain that Mo was the only variable element directly affecting phosphatase during this study. Previous work in vitro has shown that very minute quantities of Mo strongly inhibit phosphatase, whereas $\mathrm{Ca}$ and $\mathrm{Fe}$ have little or no effect at any concentration (8). It is more probable that high Fe was interfering with the uptake or translocation of Mo by the young cane. If this were true, then the apparent stimulating effects of high Fe upon phosphatase would simply reflect an Fe-induced shortage of Mo. Little information is available concerning the effects of Fe on Mo content of plants, although Warrington (23) has shown that high levels of Fe counteract Mo toxicity in soybean, peas, and flax.

The possibility of Mo-Ca-phosphatase relationships in sugarcane has been discussed in a previous paper (5), including the likelihood that Ca may block reactive sites on the enzyme or substrate molecule, and thus "protect" the reaction from Mo inhibition. The present study lends some support to this contention in that the only severe phosphatase suppression recorded for high Mo, when Ca was low and Fe high, was not repeated when Ca was raised to the high level.

Leaf amylase was generally suppressed by Mo (table 2 , item 7 ). This was not anticipated on the basis of in vitro studies (10), but nevertheless the response agrees with earlier observations of decreased amylase associated with sucrose-promoting treatments (1). A relationship of $\mathrm{Ca}$ and $\mathrm{Fe}$ with Mo, similar to that described above with regard to phosphatase, was also 
recorded. High Fe could stimulate or retard amylase, depending upon the level of Mo, but this Fe potential was confined to those plants receiving low Ca.

\section{$M o$ vs. $C a$ and $F e$, Meristem}

Meristem data (table 3) indicate that sugar and enzyme values were generally higher in meristem than leaves, but quite similar with regard to treatment effects. High Mo again increased sucrose when $\mathrm{Ca}$ was low, and, as reported for leaves, the Mo effect was curtailed when Ca was high. High iron again interfered with the high $\mathrm{Mo}$ effect when $\mathrm{Ca}$ was low, whereas no $\mathrm{Fe}$ responses were apparent when $\mathrm{Ca}$ was high, at either level of Mo.

Phosphatases were generally suppressed by high Mo in meristem. High $\mathrm{Fe}$ again appeared to stimulate phosphatases in the presence of low Ca. However, in this instance the Fe effect appeared among high-Mo treatments rather than low. The increased phosphatase activity was accompanied by a moderate sucrose decline. The Fe effect here, as suggested for leaves, possibly reflects interference by Fe with the supply of Mo to meristem tissues. Molybdenum and $\mathrm{Fe}$ analyses of the various tissues would be an excellent help in evaluating enzyme-nutrient responses of this type, since one tissue may be far more effective than another in accumulating an element, regardless of its concentration in the nutrient solution.

Amylase was suppressed in meristem by high Mo. Quite curiously, the one high-Mo treatment which stimulated amylase in meristem (i.e. in conjunction with low $\mathrm{Ca}$ and high $\mathrm{Fe}$ ), was the same treatment which most severely curtailed amylase in leaves. Since Mo is undoubtedly the agent closest to the enzyme reaction ${ }^{8}$, this supports our previous suggestion that the tissue itself, rather than the nutrient treatment, has dictated the Moenzyme response. The particular combination of low $\mathrm{Ca}$, high $\mathrm{Fe}$, and meristem tissue source apparently prohibited Mo from accumulating to an inhibitory level in the fashion of other high Mo treatments.

Invertase, which was measured for meristem only, was stimulated by high Mo, particularly in combination with low $\mathrm{Ca}$ and high Fe (table 3, item 7). High $\mathrm{Fe}$ suppressed invertase when $\mathrm{Mo}$ and $\mathrm{Ca}$ were low, but markedly stimulated the enzyme when Mo was high. Any general relationship between high Mo and invertase remains doubtful, since the effect noted during this study is practically confined to a single treatment.

8 Three other treatments of meristem, and all 4 treatments of leaves tell us that high Mo suppressed amylase. In the single instance of amylase stimulation it is assumed that $\mathrm{Mo}$ is also the critical factor, and that $\mathrm{Fe}$ and $\mathrm{Ca}$ have interfered with Mo rather than the enzyme. 
TAELE 3.-Mean values for merislem sugars, in milligrams per gram dry weight, and enzyme specific activily of immalure sugarcane supplied with variable $\mathrm{Mo}, \mathrm{Ca}$, and $\mathrm{Fe}$ in sand cullure ${ }^{1}$

\begin{tabular}{|c|c|c|c|c|c|c|c|c|c|c|c|c|c|c|}
\hline \multirow{2}{*}{ Item No. } & \multirow{2}{*}{ Data classification } & \multicolumn{13}{|c|}{ Treatment= } \\
\hline & & $\underset{\mathrm{Ca}_{3} \mathrm{Me}_{1}}{\mathrm{Mo}_{2}}$ & & $\begin{array}{l}\mathrm{Mo}_{1} \\
\mathrm{a}_{1} \mathrm{Fe}_{2}\end{array}$ & $\underset{\mathrm{Ca}_{2} \mathrm{Fo}_{1}}{\mathrm{Mo}_{1}}$ & $\underset{\mathrm{Ca}}{\mathrm{MO}_{1} \mathrm{MO}_{12}}$ & $\underset{\text { mean }}{\text { Mo1 }}$ & 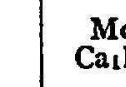 & & $\underset{\mathrm{Ca}_{1} \mathbf{M}}{\mathrm{Mo}}$ & & $\begin{array}{c}\mathrm{Mog}_{\mathbf{3}} \\
\mathrm{Ca}_{2} \mathrm{~F}_{\mathrm{i}}\end{array}$ & $\underset{\mathrm{Ca}_{2} \mathrm{FiC}_{2}}{\mathrm{MO}_{2}}$ & $\underset{\text { mean }}{\mathrm{Mo}_{2}}$ \\
\hline $\begin{array}{l}\mathbf{1} \\
\mathbf{2} \\
\mathbf{3}\end{array}$ & $\begin{array}{l}\text { Sugars } \\
\text { Total ketose } \\
\text { Sucrose } \\
\text { Fructose }\end{array}$ & $\begin{array}{l}237 \\
104 \\
133\end{array}$ & $\begin{array}{l}23 \\
12 \\
11\end{array}$ & & $\begin{array}{l}259 \\
118 \\
141\end{array}$ & $\begin{array}{l}249 \\
117 \\
132\end{array}$ & $\begin{array}{l}245 \\
116 \\
129\end{array}$ & $\begin{array}{l}273 \\
129 \\
144\end{array}$ & & $\begin{array}{l}283 \\
112 \\
171\end{array}$ & & $\begin{array}{l}263 \\
124 \\
139\end{array}$ & $\begin{array}{l}277 \\
123 \\
154\end{array}$ & $\begin{array}{l}274 \\
122 \\
152\end{array}$ \\
\hline \multirow[t]{4}{*}{$\begin{array}{l}4 \\
5 \\
\mathbf{6} \\
7 \\
8 \\
9\end{array}$} & $\begin{array}{l}\text { Enzymes } \\
\beta \text {-GP phosphatase } \\
\text { ATP-ase } \\
\text { Amylase } \\
\text { Invertase } \\
\text { Peroxidase } \\
\text { Polyphenol oxiduse }\end{array}$ & $\begin{array}{r}36.8 \\
78.1 \\
143 \\
9.3 \\
18.4 \\
17.3\end{array}$ & & $\begin{array}{l}5.3 \\
9.4 \\
9 \\
7.8 \\
8.3 \\
2.5\end{array}$ & $\begin{array}{c}36.9 \\
80.7 \\
139 \\
10.2 \\
20.9 \\
23.2\end{array}$ & $\begin{array}{r}34.1 \\
66.8 \\
128 \\
9.7 \\
17.3 \\
15.1\end{array}$ & $\begin{aligned} 35.8 \\
73.8 \\
135 \\
9.3 \\
18.7 \\
19.5\end{aligned}$ & $\begin{array}{r}31 \\
60 \\
114 \\
9 \\
17 \\
21\end{array}$ & & $\begin{array}{r}40 \\
81 \\
142 \\
17 \\
20 \\
26\end{array}$ & & $\begin{array}{l}32.2 \\
66.2 \\
109 \\
12.4 \\
15.9 \\
19.4\end{array}$ & $\begin{array}{r}30.6 \\
61.9 \\
95 \\
9.8 \\
15.2 \\
18.2\end{array}$ & $\begin{array}{c}33.5 \\
67.5 \\
115 \\
12.3 \\
17.2 \\
21.4\end{array}$ \\
\hline & Enzyme means & 50.5 & & 7.1 & 51.8 & 45.2 & 48.7 & 42 & & 54 & .6 & 42.5 & 38.5 & 44.5 \\
\hline & & \multicolumn{9}{|c|}{ Individual means } & \multicolumn{4}{|c|}{ Grand means for $\mathrm{Ca}$ and $\mathrm{Fe}$} \\
\hline & & $\begin{array}{l}\mathrm{Mol}_{1} \\
\mathrm{Ca}_{1}\end{array}$ & $\begin{array}{l}\text { Mol } \\
\mathrm{Ca}\end{array}$ & $\begin{array}{l}\mathbf{M o}_{1} \\
\mathrm{Fe}_{1}\end{array}$ & $\begin{array}{c}\mathrm{Mol} \\
\mathrm{Fez}_{2}\end{array}$ & $\begin{array}{c}\mathrm{Mo}_{2} \\
\mathrm{Ca}_{1}\end{array}$ & $\begin{array}{l}\mathrm{Mo}_{2} \\
\mathrm{Ca}=\end{array}$ & $\begin{array}{l}\mathrm{Mo}_{2} \\
\mathrm{Fe}_{1}\end{array}$ & $\begin{array}{l}\mathrm{Mc}_{\mathrm{c}} \\
\mathrm{Fc}\end{array}$ & $\mathrm{O}_{2}$ & $\mathrm{Ca}_{\mathbf{l}}$ & $\mathrm{Ca}_{2}$ & $\mathrm{Fe}_{\mathbf{I}}$ & $\mathrm{Fe}_{2}$ \\
\hline $\begin{array}{l}1 \\
2 \\
3\end{array}$ & $\begin{array}{l}\text { Sugars } \\
\text { Total ketose } \\
\text { Sucrose } \\
\text { Fructose }\end{array}$ & $\begin{array}{l}235 \\
114 \\
122\end{array}$ & $\begin{array}{l}254 \\
117 \\
137\end{array}$ & $\begin{array}{l}248 \\
111 \\
137\end{array}$ & $\begin{array}{l}241 \\
121 \\
121\end{array}$ & \begin{tabular}{|l|}
278 \\
121 \\
158
\end{tabular} & $\begin{array}{l}271 \\
123 \\
147\end{array}$ & $\begin{array}{l}268 \\
127 \\
142\end{array}$ & $\begin{array}{l}280 \\
118 \\
163\end{array}$ & & $\begin{array}{l}257 \\
117 \\
139\end{array}$ & $\begin{array}{l}262 \\
121 \\
142\end{array}$ & $\begin{array}{l}258 \\
119 \\
139\end{array}$ & $\begin{array}{l}261 \\
119 \\
142\end{array}$ \\
\hline \multirow[t]{2}{*}{$\begin{array}{l}4 \\
5 \\
7 \\
7 \\
8 \\
9\end{array}$} & $\begin{array}{l}\text { Enzymes } \\
\beta \text {-GP phosphatase } \\
\text { ATP-ase } \\
\text { Amylase } \\
\text { Invertase } \\
\text { Peroxidiase } \\
\text { Polyphenol oxidase }\end{array}$ & $\begin{array}{r}36.1 \\
73.8 \\
136 \\
8.6 \\
18.4 \\
19.9\end{array}$ & $\begin{array}{c}35.5 \\
73.8 \\
134 \\
10.0 \\
19.1 \\
19.2\end{array}$ & $\begin{array}{r}36.9 \\
79.4 \\
141 \\
9.8 \\
19.7 \\
20.3\end{array}$ & $\begin{array}{r}34.7 \\
68.1 \\
129 \\
8.8 \\
17.8 \\
18.8\end{array}$ & \begin{tabular}{|c|}
35.6 \\
71.1 \\
128 \\
13.4 \\
18.9 \\
23.9
\end{tabular} & $\begin{array}{c}31.4 \\
64.1 \\
102 \\
11.1 \\
15.6 \\
18.8\end{array}$ & $\begin{array}{c}31.6 \\
63.5 \\
112 \\
11.0 \\
16.9 \\
20.3\end{array}$ & $\begin{array}{r}35 \\
71 \\
118 \\
13 \\
17 \\
22\end{array}$ & $\begin{array}{l}5.4 \\
1.6 \\
3.5 \\
.6 \\
.6 \\
.5\end{array}$ & $\begin{array}{c}35.9 \\
72.4 \\
132 \\
10.9 \\
18.6 \\
21.9\end{array}$ & $\begin{array}{c}33.5 \\
68.9 \\
118 \\
10.5 \\
17.3 \\
18.9\end{array}$ & \begin{tabular}{|c}
34.2 \\
71.5 \\
126 \\
10.4 \\
18.3 \\
20.3
\end{tabular} & $\begin{array}{c}35.1 \\
66.1 \\
124 \\
11.2 \\
17.7 \\
20.6\end{array}$ \\
\hline & Enzyme means & 48.8 & 48.6 & 51.2 & 46.2 & 48.5 & 40.5 & 42.6 & & 3.5 & 48.6 & 44.5 & 46.8 & 45.8 \\
\hline
\end{tabular}

1 Each treatment value represents the computed mean of 4 replicates.

2 The numerals 1 and 2 refer to low- and high-treatment levels, respectively, of $\mathrm{Mo}, \mathrm{Ca}$, and Fe. 


\section{EXPERIMENT 2 (STARCH $\times$ LEAD $\times$ MOLYBDENUM)}

\section{$M o$ and $P b$ vs. Sucrose}

Highest sucrose values for both leaf and meristem tissues were obtained from plants receiving 80 p.p.m. of Mo as a foliar spray (table 4, items 7 and 14). Molybdenum at 20 p.p.m. also induced greater sucrose content (table 4 , items 6 and 13). G-1-P phosphatase was strongly suppressed among plants receiving $\mathrm{Mo}$, whereas $\beta$-glycerophosphatase and ATP-ase were only slightly suppressed in meristem, and not at all in leaves. Both the Mo effects upon sucrose and G-1-P phosphatase are in agreement with earlier results (5).

Lead, at the rate of 50 p.p.m., and to a lesser extent 500 p.p.m., caused moderate sucrose increases in both leaf and meristem (table 4, items 4 and 5, 11 and 12). G-1-P phosphatase was apparently suppressed by the $\mathrm{Pb}$ treatments in both tissue sources, but ATP-ase and $\beta$-glycerophosphatase appeared to be stimulated by $\mathrm{Pb}$ in meristem. Lead had been selected for trial, primarily because it is known to inhibit the $Q$ enzyme (7). Q enzyme itself could not be measured during the present study because of the elaborate preparation required of even a single sample, but nevertheless some relationship between $\mathrm{Pb}$ and starch formation was expressed as a $\mathrm{Pb}$-inhibitor of starch phosphorylase (table 4, items 4 and 5). A decreased starch phosphorylase reaction and increased sucrose are logical side-effects of a suppressed $\mathrm{Q}$ enzyme. Invertase of sugarcane is also inhibited by $\mathrm{Pb}$ in vitro (9), but no invertase inhibition was recorded for $\mathrm{Pb}$ during the present study.

Starch had been applied in an effort to stimulate amylase, thereby demonstrating that a function of amylase is the removal of excess starch. Amylase was not stimulated by the starch treatments, and in meristem amylase decreased among those plants treated with a 1-percent starch solution (table 4, item 10). This was the only relationship established between applied starch and endogenous amylase.

\section{EXPERIMENT 3 ( $\beta$-GP $\times$ BORON $\times$ TCA)}

The only treatment to seriously alter sucrose during experiment 3 was the foliar spray of 1-percent TCA. This reduced sucrose in leaves at 10 and 30 days following treatment, and at 30 days in meristem (table 5, items 14 and 21 ; table 6 , item 21 ). Trichloroacetic acid at 0.1 percent induced similar effects in meristem at 30 days.

Trichloroacetic acid did not appear to behave as an enzyme inhibitor, as it does so well in the test tube, but rather stimulated each of the five enzymes measured. This effect was most apparent for both leaf and meristem enzymes at the 30-day harvest (tables 5 and 6, items 20 and 21). It is believed, 
TABLE 4.-Mean values for sugars and enzyme specific activity of immature sugarcane 20 days following foliar application of starch, $\mathrm{Pb}$, and $\mathrm{MO}^{1}$

\begin{tabular}{|c|c|c|c|c|c|c|c|c|c|c|c|}
\hline \multirow{3}{*}{ Tissue } & \multirow{3}{*}{$\begin{array}{l}\text { Item } \\
\text { No. }\end{array}$} & \multirow{3}{*}{ Treatment } & \multicolumn{9}{|c|}{ Data classification } \\
\hline & & & \multicolumn{3}{|c|}{$\begin{array}{c}\text { Sugars } \\
\text { (mg./gm. dry weight })\end{array}$} & \multicolumn{6}{|c|}{ Enzymes } \\
\hline & & & $\begin{array}{l}\text { Total } \\
\text { ketose }\end{array}$ & crose & $\begin{array}{l}\text { Fruc- } \\
\text { tose }\end{array}$ & $\begin{array}{c}\beta- \\
\text { glycero- } \\
\text { phos- } \\
\text { phatase }\end{array}$ & ATP- & $\begin{array}{c}\text { G-1-P } \\
\text { phos- } \\
\text { phatase }\end{array}$ & $\begin{array}{l}\text { Am- } \\
\text { ylase }\end{array}$ & $\begin{array}{l}\text { Starch- } \\
\text { phos- } \\
\text { phor- } \\
\text { ylase }\end{array}$ & $\begin{array}{l}\text { Enzyme } \\
\text { means }\end{array}$ \\
\hline \multirow[t]{9}{*}{ Leaf } & 1 & Control & 96.1 & 73.5 & 22.5 & 11.9 & 21.9 & 9.2 & 29.1 & 30.0 & 20.4 \\
\hline & 2 & $\begin{array}{c}\text { Starch, } 0.1 \\
\text { percent }\end{array}$ & 87.3 & 71.1 & 16.1 & 12.5 & 22.3 & 6.7 & 27.4 & 15.7 & 16.9 \\
\hline & 3 & $\begin{array}{c}\text { Starch, } 1.0 \\
\text { percent }\end{array}$ & 85.9 & 73.1 & 12.9 & 11.3 & 19.2 & 4.5 & 25.2 & 17.6 & 15.6 \\
\hline & 4 & $\mathrm{~Pb}, 50$ p.p.m. & 106.1 & 92.5 & 13.5 & 11.6 & 18.2 & 5.1 & 25.2 & 19.8 & 15.9 \\
\hline & 5 & $\mathrm{~Pb}, 500$ & 102.3 & 86.0 & 16.2 & 14.9 & 25.0 & 5.9 & 30.8 & 22.4 & 19.8 \\
\hline & 6 & $\begin{array}{l}\text { p.p.m. } \\
\text { Mo, } 20 \text { p.p.m. }\end{array}$ & 104.7 & 91.9 & 12.8 & 11.5 & 18.8 & 3.9 & 21.7 & 17.9 & 14.8 \\
\hline & 7 & Mo, 80 p.p.m & .111 .2 & 99.5 & 11.7 & 16.4 & 21.7 & 4.5 & 34.4 & 32.2 & 21.8 \\
\hline & & Means & 99.1 & 83.9 & 15.1 & 12.9 & 21.0 & 5.7 & 27.7 & 22.2 & 17.9 \\
\hline & & & $\begin{array}{l}\text { Total } \\
\text { ketose }\end{array}$ & $\mid \begin{array}{c}\text { Su- } \\
\text { crose }\end{array}$ & $\begin{array}{l}\text { Fruc- } \\
\text { tose }\end{array}$ & $\begin{array}{l}\text { } \beta- \\
\text { glycero- } \\
\text { phos- } \\
\text { phatase }\end{array}$ & $\underset{\text { ase }}{\operatorname{ATp}}$ & $\begin{array}{l}\text { G-1-P } \\
\text { phos- } \\
\text { phatase }\end{array}$ & Al $\mathrm{Am-}$ & $\begin{array}{l}\text { Invet- } \\
\text { tase: }\end{array}$ & $\begin{array}{l}\text { Enzyme } \\
\text { means }\end{array}$ \\
\hline \multirow{8}{*}{$\begin{array}{l}\text { Meri- } \\
\text { stem }\end{array}$} & 8 & Control & 196.0 & 98.3 & 97.7 & 22.0 & 33.5 & 9.9 & 70.4 & 7.7 & 28.5 \\
\hline & 9 & $\begin{array}{c}\text { Starch, } 0.1 \\
\text { percent }\end{array}$ & 190.7 & 100.8 & 89.9 & 25.1 & 38.3 & 8.5 & (ici.3 & 9.2 & 29.5 \\
\hline & 10 & $\begin{array}{c}\text { Starch, } 1.0 \\
\text { percent }\end{array}$ & 193.1 & 95.9 & 100.1 & 19.1 & 27.5 & 7.6 & 50.5 & 6.8 & 22.3 \\
\hline & 11 & $\mathrm{~Pb}, 50$ p.p.m & .208 .0 & 114.0 & 94.0 & 27.8 & 41.7 & 7.1 & 76.8 & 8.3 & 32.3 \\
\hline & 12 & $\begin{array}{r}\mathrm{Pb}, \mathbf{5 0 0} \\
\text { p.p.m. }\end{array}$ & 207.2 & $\mid 108.7$ & 98.5 & 26.9 & 39.1 & 7.9 & 73.3 & 9.5 & 31.3 \\
\hline & 13 & Mo, 20 p.p.m & 207.7 & 120.9 & 87.9 & 19.0 & 28.2 & 5.8 & 55.4 & 5.3 & 22.7 \\
\hline & 14 & Mo, 80 p.p.m & . 198.3 & 124.9 & 73.0 & 20.9 & 30.5 & 5.9 & 59.0 & 6.5 & 24.6 \\
\hline & & Means & 200.1 & 109.1 & 91.6 & 23.0 & 34.3 & 7.5 & 64.5 & 7.6 & 27.3 \\
\hline
\end{tabular}

${ }^{1}$ Each figure represents the computed mean of 3 replicates.

2 Invertase for items 8 to 14 , meristem.

however, that the initial effect of TCA upon enzymes must have been suppression, that those enzymes actually exposed to the freshly applied TCA were likely inhibited in much the same manner as they are in the test tube. The plants must then have reacted to correct these effects by synthesizing new enzyme protein. This cannot be done in vitro. Thus the measurements 
taken 30 days after treatment appear to record a new physiological state of affairs, one in which enzymes of sucrose metabolism are slightly predominant over those of sucrose formation. The fact that enzymes were

TABLE 5.-Mean values for leaf sugars and enzyme specific activity of immature sugarcane receiving foliar applications of $\beta-G P, B$, and $T C A^{1}$

\begin{tabular}{|c|c|c|c|c|c|c|c|c|c|c|}
\hline \multirow{3}{*}{$\begin{array}{c}\text { Days } \\
\text { follow- } \\
\text { ing } \\
\text { treat- } \\
\text { ment }\end{array}$} & \multirow{3}{*}{$\begin{array}{l}\text { Item } \\
\text { No. }\end{array}$} & \multirow{3}{*}{ Treatment } & \multicolumn{8}{|c|}{ Data classification } \\
\hline & & & \multicolumn{3}{|c|}{$\begin{array}{l}\text { Leaf sugars } \\
\text { (mg./gm. dry weight }\end{array}$} & \multicolumn{4}{|c|}{ Enzymes } & \multirow{2}{*}{$\begin{array}{r}\text { En- } \\
\text { zyme } \\
\text { means }\end{array}$} \\
\hline & & & $\begin{array}{l}\text { Total } \\
\text { ketose }\end{array}$ & Sucrose & $\begin{array}{c}\text { Fruc- } \\
\text { tose }\end{array}$ & $\begin{array}{c}\beta \text {-GP- } \\
\text { ase }\end{array}$ & $\underset{\text { ase }}{\text { ATP- }}$ & $\underset{\text { ylase }}{\text { Am- }}$ & $\begin{array}{l}\text { Starch } \\
\text { phos- } \\
\text { phor- } \\
\text { ylase }\end{array}$ & \\
\hline \multirow[t]{8}{*}{$\mathbf{0}$} & 1 & Control & 63.2 & 56.4 & 6.8 & 20.6 & 48.8 & 175 & 31.3 & 68.9 \\
\hline & 2 & $\beta$-GP, 100 p.p.m. & 65.9 & 59.1 & 6.8 & 19.6 & 45.3 & 187 & 32.0 & 70.9 \\
\hline & 3 & $\beta$-GP, 1,000 p.p.m. & 70.9 & 61.6 & 9.3 & 24.0 & 56.1 & 200 & 32.3 & 78.1 \\
\hline & 4 & B, 50 p.p.m. & 71.5 & 64.1 & 7.4 & 16.8 & 39.2 & 145 & 24.3 & 56.3 \\
\hline & 5 & B, 500 p.p.m. & 76.9 & 65.2 & 11.6 & 26.9 & 58.9 & 208 & 43.9 & 84.4 \\
\hline & 6 & TCA, .1 percent & 62.3 & 56.0 & 6.3 & 25.3 & 65.1 & 229 & 43.7 & 90.8 \\
\hline & 7 & TCA, 1.0 percent & 65.3 & 56.5 & 8.8 & 20.9 & 50.2 & 186 & 32.3 & 72.4 \\
\hline & & Means & 68.0 & 59.8 & 8.1 & 22.0 & 51.9 & 190 & 34.3 & 74.5 \\
\hline \multirow[t]{8}{*}{10} & 8 & Control & 129.7 & 127.1 & 2.6 & 11.5 & 19.3 & 97 & 15.3 & 35.8 \\
\hline & 9 & $\beta$-GP, 100 p.p.m. & 132.6 & 129.6 & 3.0 & 12.3 & 21.1 & 107 & 10.1 & 37.6 \\
\hline & 10 & $\beta$-GP, 1,000 p.p.m. & 119.6 & 115.3 & 4.6 & 11.6 & 19.2 & 88 & 12.8 & 32.9 \\
\hline & 11 & B, 50 p.p.m. & 131.2 & 123.4 & 7.8 & 13.0 & 22.9 & 88 & 7.5 & 32.9 \\
\hline & 12 & B, 500 p.p.m. & 140.6 & 132.0 & 8.6 & 12.9 & 21.7 & 98 & 14.8 & 36.9 \\
\hline & 13 & TCA, .1 percent & 129.4 & 121.4 & 8.0 & 12.5 & 20.7 & 101 & 18.9 & 38.3 \\
\hline & 14 & TCA, 1.0 percent & 96.0 & 85.0 & 11.3 & 14.7 & 22.6 & 96 & 16.0 & 37.3 \\
\hline & & Means & 125.6 & 119.1 & 6.6 & 12.6 & 21.1 & 96 & 13.6 & 35.9 \\
\hline \multirow[t]{8}{*}{30} & 15 & Control & 120.1 & 114.0 & 6.1 & 8.8 & 17.0 & 74 & 16.6 & 29.1 \\
\hline & 16 & $\beta$-GP, 100 p.p.m. & 123.9 & 104.9 & 18.9 & 10.1 & 18.7 & 88 & 17.0 & 33.5 \\
\hline & 17 & $\beta-G P, 1,000$ p.p.m. & 123.2 & 92.5 & 30.7 & 9.8 & 18.4 & 84 & 21.2 & 33.4 \\
\hline & 18 & B, 50 p.p.m. & 119.4 & 84.6 & 34.7 & 11.4 & 19.5 & 106 & 14.5 & 37.9 \\
\hline & 19 & B, 500 p.p.m. & 127.8 & 107.1 & 20.6 & 8.8 & 16.0 & 75 & 15.9 & 28.9 \\
\hline & 20 & TCA, 1 percent & 119.4 & 99.9 & 19.4 & 10.3 & 20.6 & 98 & 20.4 & 37.3 \\
\hline & 21 & TCA, 1.0 percent & 100.8 & 82.5 & 18.3 & 12.5 & 24.2 & 85 & 20.7 & 35.6 \\
\hline & & Means & 119.2 & 97.9 & 21.2 & 10.2 & 19.2 & 87 & 18.0 & 33.7 \\
\hline
\end{tabular}

1 Each figure represents the computed mean of 3 replicates.

more stimulated at 30 than at 10 days is evidence that we had measured the consequences of TCA rather than its immediate effects.

Boron, at the rate of 500 p.p.m., caused small increases of leaf sucrose at 
10 and 30 days (table 5 , items 12 and 19). This treatment had stimulated meristem invertase at 10 days (table 6 , items 12 and 19), but at 30 days a depression of both invertase and amylase was recorded for meristem. Leaf

TABLE 6.-Mean values for meristem sugar's and enzyme specific activity of immature sugarcane receiving foliar applicalions of $\beta-G P, B$, and TCA ${ }^{1}$

\begin{tabular}{|c|c|c|c|c|c|c|c|c|c|c|}
\hline \multirow{3}{*}{$\begin{array}{l}\text { Days } \\
\text { follow- } \\
\text { ing } \\
\text { treat- } \\
\text { ment }\end{array}$} & \multirow{3}{*}{$\begin{array}{l}\text { Item } \\
\text { No. }\end{array}$} & \multirow{3}{*}{ Treatment } & \multicolumn{8}{|c|}{ Data classifcation } \\
\hline & & & \multicolumn{3}{|c|}{$\begin{array}{l}\text { Leaf sugars } \\
\text { (mg./gm. dry weight) }\end{array}$} & \multicolumn{4}{|c|}{$\underset{\text { (specific activity) }}{\text { Enzymes }}$} & \multirow{2}{*}{$\begin{array}{l}\text { Enzyme } \\
\text { means }\end{array}$} \\
\hline & & & $\begin{array}{c}\text { Total } \\
\text { ketose }\end{array}$ & Sucrose & $\begin{array}{c}\text { Fruc- } \\
\text { tose }\end{array}$ & $\mid \begin{array}{c}\beta- \\
\text { GPase }\end{array}$ & $\underset{\text { ase }}{\operatorname{ATP}}$ & $\begin{array}{c}\text { Am- } \\
\text { ylase }\end{array}$ & $\begin{array}{c}\text { Inver- } \\
\text { tase }\end{array}$ & \\
\hline \multirow[t]{8}{*}{0} & 1 & Control & 146.6 & 27.9 & 118.8 & 28.2 & 41.2 & 105 & 10.5 & 46.2 \\
\hline & 2 & ק-GP, 100 p.p.m. & 144.5 & 22.3 & 122.3 & 29.1 & 36.7 & 115 & 9.1 & 47.5 \\
\hline & 3 & $\beta$-GP, 1,000 p.p.m. & 161.5 & 24.3 & 137.2 & 23.4 & 29.4 & 104 & 8.0 & 41.2 \\
\hline & 4 & B, 50 p.p.m. & 152.1 & 22.7 & 129.5 & 29.0 & 43.1 & 116 & 11.6 & 49.9 \\
\hline & 5 & B, 500 p.p.m. & 155.8 & 23.7 & 132.1 & 25.5 & 29.5 & 102 & 10.3 & 41.8 \\
\hline & 6 & TCA, 0.1 percent & 133.8 & 15.1 & 118.4 & 35.2 & 57.1 & 143 & 12.4 & 61.9 \\
\hline & \multirow[t]{2}{*}{7} & TCA, 1.0 percent & 143.2 & 18.5 & 124.7 & 29.1 & 40.0 & 91 & 11.4 & 42.9 \\
\hline & & Means & 148.2 & 22.1 & 126.1 & 28.5 & 39.6 & 111 & 10.5 & 47.3 \\
\hline \multirow[t]{8}{*}{10} & 8 & Control & 176.3 & \begin{tabular}{|l|}
69.7 \\
\end{tabular} & 106.5 & 19.4 & 17.2 & 44.1 & 6.9 & 21.9 \\
\hline & 9 & $\beta$-GP, 100 p.p.m. & 180.9 & 72.9 & 108.0 & 20.3 & 18.5 & 45.6 & 6.4 & 22.7 \\
\hline & 10 & $\beta$-GP, 1,000 p.p.m. & 170.5 & 66.0 & 104.5 & 20.4 & 18.5 & 49.5 & 6.7 & 23.7 \\
\hline & 11 & B, 50 p.p.m. & 184.9 & 70.4 & 114.5 & 22.4 & 18.9 & 44.9 & 8.8 & 23.7 \\
\hline & 12 & B, 500 p.p.m. & 186.7 & 79.5 & 107.2 & 23.4 & 21.0 & 44.9 & 9.4 & 24.7 \\
\hline & 13 & TCA, 0.1 percent & 184.4 & 71.6 & 112.8 & 22.9 & 20.2 & 42.9 & 8.6 & 23.7 \\
\hline & \multirow[t]{2}{*}{14} & TCA, 1.0 percent & 200.3 & 72.5 & 107.7 & 29.4 & 28.8 & 58.2 & 10.9 & 31.8 \\
\hline & & Means & 183.4 & 74.7 & 108.7 & 22.6 & 20.4 & 47.2 & 8.2 & 24.6 \\
\hline \multirow[t]{8}{*}{30} & 15 & Control & 170.1 & 102.8 & 67.3 & 25.1 & 28.9 & 74.0 & 8.1 & 34.0 \\
\hline & 16 & $\beta$-GP, 100 p.p.m. & 188.5 & 105.5 & 83.1 & 20.7 & 22.5 & 61.1 & 6.5 & 27.7 \\
\hline & 17 & $\beta$-GP, 1,000 p.p.m. & 203.2 & 112.1 & 91.1 & 24.8 & 25.6 & 64.6 & 9.1 & 31.0 \\
\hline & 18 & B, 50 p.p.m. & 200.5 & 101.7 & 98.8 & 28.6 & 28.4 & 63.7 & 11.2 & 32.9 \\
\hline & 19 & B, 500 p.p.m. & 191.8 & 112.4 & 79.5 & 24.0 & 25.7 & 54.5 & 6.2 & 27.6 \\
\hline & 20 & TCA, 0.1 percent & 181.3 & 88.5 & 92.9 & 29.9 & 35.3 & 89.3 & 8.4 & 40.7 \\
\hline & \multirow[t]{2}{*}{21} & TCA, 1.0 percent & 190.0 & 87.2 & 102.8 & 29.1 & 34.0 & 74.0 & 10.1 & 36.8 \\
\hline & & Means & 189.3 & 101.5 & 87.9 & 26.0 & 28.6 & 68.7 & 8.5 & $\begin{array}{l}52.9 \\
52\end{array}$ \\
\hline
\end{tabular}

1 Each figure represents the computed mean of 3 replicates.

enzymes were not affected by 500 p.p.m. of B, although $B$ at 50 p.p.m. suppressed invertase at 10 days and increased amylase at 30 days. A relationship apparently exists between B and the enzymes invertase and amyl- 
ase in cane, but the nature of this relationship will have to await further studies.

SIGNIFICANCE OF INDUCED SUCROSE-ENZYME RELATIONSHIPS

Several points brought forward by the present experiments should now be viewed in perspective, particularly the concept that enzyme-regulating materials might be gainfully applied to cane. The complex consequences of such treatments when applied to living tissues, as opposed to a strictly in vitro environment, need also to be reviewed.

Perhaps the most important observation of this work is the fact that Mo seems fully capable of stimulating sucrose formation, whether supplied through roots or foliage. The mode of Mo action appears to be the suppression of G-1-P phosphatase, in accordance with earlier observations, although evidence of amylase and invertase relationships is now available.

In another sense these experiments have emphasized an apparent futility of sceking in vivo effects on the basis of in vitro observations, or on the basis of another investigator's observations with another plant species. Nevertheless, several concepts are evident which account for the unexpected in vivo responses. First, the plant has resources at its disposal to counteract the effects of an otherwise potent treatment, and these are not available in the test tube. Molybdenum, for all its potential for suppression of phosphatases, can apparently be counteracted by other elements which in themselves have little or no power over the enzymes. For the plant this is probably just a routine matter of mobilizing and translocating other elements already within its tissues, or of drawing upon them from its nutritional environment. The investigator may employ nutrient analyses to help clarify such changes being made by the plant.

A second important feature of the living plant is its capacity to synthesize new enzyme protein when necessary. The loss of part of its normal enzyme complement might well enable a plant to synthesize even more enzyme, or more powerful enzyme, than was present before the inhibitory treatment was applied. This seems to have happened here as a consequence of the TCA treatments. The mechanism of enzyme synthesis is one of the most fundamental of all biochemical problems, and remains basically unsolved beyond the stages of essential precursors and energy supply $(18, \mathrm{p}$. $369)$. Investigators have accomplished the in vitro synthesis of $\beta$-galactosidase (15) and socalled "false proteins" $(19,12)$, but, to our knowledge, no studies have been conducted of enzyme synthesis in sugarcane. The eventual understanding of enzyme formation in cane will provide tools for investigating enzyme-sucrose relationships in far greater depth than is now possible.

A third factor of importance is the different behavior of enzymes accord- 
ing to tissue source. An enzyme-treatment response noted in leaves does not necessarily appear in meristem, and a response observed in both tissues might vary as to time of appearance or treatment level at which it is induced. In some instances the relative proportions of interfering nutrients may account for such behavior, and, at such times, enzyme behavior is itself an expression of the nutrient-element balance concept proposed by Shear, Crane, and Myers (21). But it must not be supposed that there is normally a uniformity of action between tissues, or even within the different parts of a single tissue. An excellent example is presented by the work of Jensen (17), who studied IAA-induced peroxidase formation in roots of Vicia faba. Whereas cells of the rootcap, proepidermis, and vascular tissue, including the protophloem and protoxylem, contained peroxidase, only the vascular tissue clearly showed the induced formation of peroxidase. The maximum response to IAA shifted from early provascular tissue at $10^{-8} \mathrm{M}$ to the developing protoxylem at $10^{-7} \mathrm{M}$. Furthermore, since it had already been shown that peroxidase is an essential component of the IAA oxidase system (16), the work of Jensen demonstrated that applied IAA can help induce the means of its own destruction.

The preference of sugarcane enzymes for specific tissues is being established. In previous studies at this laboratory, the $Q$ enzyme has been shown to predominate in mature leaves (7), and invertase in node and meristem tissues $(9)$. Phosphatases are highly active in meristem and 8 to 10 internodes (8), and amylase in immature leaves (10). Enzyme source is a major problem when sampling sugarcane, since there is obviously a limit as to the number of samples that can be accommodated. We have settled upon leaves +1 to +4 as being the most representative single source of enzyme protein in cane.

A final consideration when dealing with enzymes in vivo is the fact that they are components of biochemical sequences, and do not exist as the isolated, relatively independent entities they appear to be in the test tube. Whether these sequences have a definite physical or spatial relationship is debatable, but without question the action of a single enzyme depends greatly upon the welfare of its biochemical "neighbors". Sucrose and hexose levels in particular are related to enzymes of glycolysis and of the Krebs cycle (1).

The existence of biochemical "chain reactions" accounts better than any other concept for otherwise unaccountable enzyme-nutrient and enzymesugar responses. During the present study, there were instances when stimulated invertase appeared in tissues where sucrose increased, and phosphatase was stimulated by Mo treatments when we know that Mo is a deadly inhibitor of phosphatase. Amylase was inhibited by Mo when it is 
known that this does not happen in vitro. In all probability we were measuring consequences of unmeasured (possibly unmeasurable) reactions taking place at some other site in a single biochemical pattern.

Attempts to regulate plant enzymes toward one's own ends is much like a game of chess, in which the factors of time, experience, familiarity, and depth of resources are overwhelmingly gathered on the side of the plant. Some small and temporary successes are perhaps all the investigator can hope for, and yet, in the instance of sugarcane, an increase of sucrose might well be worth the effort.

\section{SUMMARY}

Variable levels of the elements molybdenum, calcium, iron, lead, and boron, as well as trichloroacetic acid, $\beta$-glycerophosphate, and starch, were supplied to immature sugarcane grown in the greenhouse. Molybdenum, calcium, and iron were provided in factorial combination to plants in sand culture. Molybdenum, lead, and starch were applied as foliar sprays to a second group of plants grown in soil, and boron, $\beta$-glycerophosphate, plus trichloroacetic acid were likewise applied to the foliage of plants grown in soil.

The objectives of these experiments were to determine whether any of the applied materials could alter the action of specific enzymes, and, if so, whether significantly greater sucrose content would result. Leaf and meristem tissues were assayed for sugars, and for the enzymes amylase, invertase, acid phosphatases, starch phosphorylase, peroxidase, and polyphenol oxidase.

Molybdenum significantly increased sucrose when applied as a foliar spray (80 p.p.m.), and as a nutrient in sand culture (1 p.p.m.). The molybdenum effect was retarded or reversed when either high calcium ( 9 p.p.m.) or high iron (6 p.p.n.) was supplied concurrently. Acid phosphatases and amylase were suppressed by high molybdenum, although these effects were greatly dependent upon calcium and iron supply. When applied as a foliar spray, molybdenum suppressed amylase and the phosphatase hydrolyzing glucose-1-phosphate, but not ATP-ase or $\beta$-glycerophosphatase.

Invertase was suppressed by high iron (6 p.p.m.) when molybdenum and calcium were low, but was stimulated when molybdenum was high.

Lead, when applied to leaves at the rate of 50 p.p.m., caused moderate sucrose increases. Glucose-1-phosphate phosphatase was suppressed by lead in leaves and meristem, as was starch phosphorylase in the leaves. Foliar starch application failed to stimulate amylase, while $\beta$-glycerophosphate failed to inhibit starch phosphorylase or to induce greater phosphatase activity.

A number of enzyme responses were obtained which do not happen in 
vitro, and known in vitro effects did not always appear when specific materials were applied to living plants. Trichloroacetic acid, in particular, appeared to stimulate rather than inhibit enzyme action in vivo. This and other consequences of applying enzyme-regulating materials are discussed in detail.

\section{RESLMEN}

A caña inmadura sembrada en invernaderos, se le aplicó molibdeno, calcio, hierro, plomo y boro a niveles variables, a la vez que ácido tricloroacético, $\beta$-glicerofosfato y almidón. A plantas sembradas en arena se les aplicó molibdeno, calcio y hierro en combinaciones factoriales. Se hicieron aspersiones foliares de molibdeno, plomo y almidón a un segundo grupo de plantas cultivadas en tierra, e igualmente se les asperjó el follaje a plantas sembradas en tierra usando boro, $\beta$-glicerofosfato y ácido tricloroacético.

El propósito de estos experimentos fue determinar si alguno de los materiales usados podía alterar la acción de enzimas específicas y, de ser así, si tal cosa produciría un aumento significativo en el contenido de sacarosa en la caña. Se analizaron tejidos de hoja y meristemo para determinar el contenido de azúcares y la presencia de las siguientes enzimas: amilasa, invertasa, fosfatasas ácidas, fosforilasa de almidón, peroxidasa y oxidasa de polifenol.

El molibdeno aumentó la sacarosa significativamente al aplicarse como aspersión foliar (80 p.p.m.), y como nutrimento en los cultivos de arena (1 p.p.m.). El efecto del molibdeno se retardó o revirtió al hacerse conjuntamente, a niveles altos aplicaciones de calcio $(9$ p.p.m.) o de hierro (6 p.p.m.). El molibdeno aplicado a niveles altos suprimió la acción de las fosfatasas y la amilasa, aunque tales efectos dependieron en gran medida del abastecimiento de calcio y hierro. Cuando se aplicó en forma de aspersión foliar, el molibdeno suprimió la acción de la amilasa y la fosfatasa, hidrolizando el fosfato de glucosa-1, pero no así la ATP-asa o la $\beta$-glicerofosfatasa.

La acción de la invertasa se suprimió al tratarse ésta con altos niveles de hierro ( 6 partes por millón) en presencia de bajos niveles de molibdeno y calcio, pero se estimuló cuando el nivel del molibdeno era alto.

El plomo causó aumentos moderados en la sacarosa cuando se aplicó al follaje, a razón de 50 partes por millón. La fosfatasa del fosfato de glucosa-1 quedó suprimida en presencia de plomo en las hojas y el meristemo. Lo mismo le ocurrió a la fosforilasa de almidón en las hojas. La aspersión del follaje con almidón no tuvo efecto estimulante sobre la amilasa, mientras que el $\beta$-glicerofostato no inhibió la fosforilasa de almidón ni indujo una mayor actividad a la fosfatasa.

Se obtuvo un número de reacciones enzimáticas que nunca tienen lugar in vitro, y por otro lado no aparecieron conocidas reacciones in vitro, cuando 
se aplicaron maleriales especificos a las plantas vivas. El ácido tricloroacético, en particular, aparentemente estimuló antes que inhibió la acción enzimática in vivo. Se discuten detalladamente este y otros resultados que siguieron a la aplicación de materiales reguladores de las enzimas.

\section{LITERATURE CITED}

1. Alexander, A. G., Sucrose-enzyme relationships in immature sugarcane as affected by variable nitrate and potassium supplied in sand culture, $J . A g r$. Univ. P.R. 48 (3): 165-231, 1964.

2. - Behavior of enzymes governing starch- and sucrose-forming pathways in two sugarcane varieties supplied with variable nitrate and phosphate in sand culture, J. Agr. Univ. P.R. 49 (2): 153-75, 1965.

3. - Changes in leaf-sugar content and enzyme activity of immature sugarcane following foliar application of indole-3-acetic acid, 2,4-dichlorophenoxyacetic acid, and maleic hydrazide, J. Agr. Univ. P.R. 49 (1): 1-34, 1965.

4. - The biosynthesis of sucrose in sugarcane, J. Agr. Univ. P.R. 48 (4): 265-83, 1964.

5. - Induction of varying sugar levels in leaves of immature sugarcane by use of acid phosphatase inhibitors, J. Agr. Univ. P.R. 49 (1): 35-59, 1965.

6. - Physiological studies of enzymes catalyzing the synthesis and hydrolysis of sucrose, starch, and phosphorylated hexose in sugarcane, J. Agr. Univ. P.R. 49 (1): 60-75, 1965.

7. - Hydrolytic proteins of sugarcane: The Q enzyme, J. Agr. Univ. P.R. 49 (2): 176-203, 1965.

8. - Hydrolytic proteins of sugarcane: The acid phosphatases, J. Agr. Univ. P.R. 49 (2) : 204-28, 1965.

9. - , Hydrolytic proteins of sugarcane: The acid invertases, J. Agr. Univ. P.R. 49 (3): 287-307, 1965.

10. - , Hydrolytic proteins of sugarcane: Amylase, J. Agr. Univ. P.R. 49 (3):308$24,1965$.

11. Cardini, C. E., Leloir, L. F., and Chiriboga, J., The biosynthesis of sucrose, $J$. Biol. Chem. 214: 149-55, 1955.

12. Cohen, G. N., and Cowie, D. B., Total replacement of methionine by selenomethionine in proteins of Escherichia coli, Compte. Rend. Acad. Sci. 244: 680-83, 1957; Chem. Abs. 51: 8210, 1957.

13. Dugger, W.M., and Humphreys, T. E., Influence of boron on enzymatic reactions associated with biosynthesis of sucrose, Plant Physiol. 35: 523-30, 1960.

14. Fruton, J. S., and Simmonds, S., General Biochemistry, John Wiley \& Sons, Inc., New York, N.Y., 1959.

15. Gale, E. F., and Folkes, J. P.. Effect of nucleic acids on protein synthesis and amino-acid incorporation in disrupted staphylococcal cells, Nature 178: 1223-7, 1954.

16. Galston, A. W., Bonner, J., and Baker, R. S., Flavoprotein and peroxidase as components of the indoleacetic acid oxidase system of peas, Arch. Biochem. Biophys. 48: 456-70, 1953.

17. Jensen, W. A., The histochemical localization of peroxidase in roots and its induction by indoleacetic acid, Plant Physiol. 30: 426-32, 1955.

18. Neilands, J. B., and Stumpf, P. K., Outlines of Enzyme Chemistry, 2nd. ed., John Wiley \& Sons, Inc., New York, N.Y., 1964. 
19. Pardee, A. B., Shore, V. G., and Prestidge, L. S., Incorporation of azatryptophan into proteins of bacteria and bacteriophage, Biochem. et. Biophys. Acta, 21: 406-7, 1956; Chem. Abs., 50: 16976, 1956.

20. Roe, J, R., A colorimetric method for the determination of fructose in blood and urine, J. Biol. Chem. 107: 15-22, 1934.

21. Shear, C. B., Crane, H. L., and Meyers, A. T., Nutrient-element balance: A fundamental concept in plant nutrition. Proc. Amer. Soc. Hort. Sci. 47: 239-48, 1945.

22. Sutherland, E. W., Cori, C. F., Haynes, R., and Olsen, N. S., Purification of the hyperglycemic-glycogenolytic factor from insulin and from gastric mucosa, J. Biol. Chem. 180: 825-37, 1949.

23. Warington, $\mathbf{K}$., The influence of iron supply on toxic effects of manganese, molybdenum, and vanadium on soybean, peas and flax, An. Appl. Biol. 41: 1-22, 1954. 